\title{
A-102395, a New Inhibitor of Bacterial Translocase I, Produced by Amycolatopsis sp. SANK 60206
}

\author{
Ryo Murakami, Yoko Fujita, Masaaki Kizuka, Tomoka Kagawa, Yasunori Muramatsu, \\ Shunichi Miyakoshi, Toshio Takatsu, Masatoshi Inukai
}

Received: August 22, 2007 / Accepted: October 16, 2007

(C) Japan Antibiotics Research Association

\begin{abstract}
Bacterial phospho- $N$-acetylmuramyl-pentapeptide translocase (translocase I: EC 2.7.8.13) is a key enzyme in peptidoglycan biosynthesis, and a known target of antibiotics. Here we report a new nucleoside inhibitor for translocase I, A-102395, isolated from the culture broth of the strain Amycolatopsis sp. SANK 60206. A-102395 is a new derivative of capuramycin that has the benzene with a uniquely substituted chain instead of an aminocaprolactam. A-102395 is a potent inhibitor of bacterial translocase I with $\mathrm{IC}_{50}$ value of $11 \mathrm{nM}$, but possesses no antimicrobial activity against various strains tested.
\end{abstract}

Keywords translocase I, peptidoglycan, nucleoside inhibitor, capuramycin, Amycolatopsis sp., antimicrobial activity

\section{Introduction}

The need for new classes of antibiotics is growing as the emergence of antibiotics resistance continues to spread worldwide. Enzymes responsible for the biosynthesis of the peptidoglycan components of the bacterial cell wall are essential for growth, and therefore are well precedented targets for antibiotics. Among these enzymes, phospho- $N$ - acetylmuramyl-pentapeptide translocase (translocase I) catalyzes the first membrane step of peptidoglycan biosynthesis. It transfers MurNAc-pentapetide from UDPMurNAc-pentapetide to the lipid carrier, undecaprenyl phosphate to form lipid I. There are some compounds reported as translocase I inhibitors [1], such as mureidomycins [2], pacidamycins [3], napsamycins [4], liposidomycins [5], tunicamycin [6], capuramycins [7 13], muraymycins [14] and caprazamycins [15, 16]. They exhibit antimicrobial activity against various strains including multidrug-resistant stains, and show bactericidal activity $[15,17,18]$. Thus translocase $I$ is an established target for the search of novel antibiotics.

In the course of our screening for bacterial translocase I inhibitors, we found inhibitory activity in the culture broth of Amycolatopsis sp. SANK 60206. In this paper, we describe the taxonomy and fermentation of the producing microorganism, isolation, physico-chemical properties, structure elucidation and biological activities of A-102395.

\section{Materials and Methods}

\section{Materials}

Undecaprenyl phosphate was purchased from Larodan Fine
R. Murakami (Corresponding author): Exploratory Research Laboratories II, Daiichi-Sankyo Co., Ltd., 1-16-13, Kitakasai, Edogawa-ku, Tokyo 134-8630, Japan,

E-mail: murakami.ryo.bw@daiichisankyo.co.jp

Y. Fujita, M. Kizuka, T. Kagawa, T. Takatsu: Advanced Technology Research Laboratories, Daiichi-Sankyo Co., Ltd., 1-2-58, Hiromachi, Shinagawa-ku, Tokyo 140-8710, Japan
Y. Muramatsu: Exploratory Research Laboratories I, DaiichiSankyo Co., Ltd., 1-16-13, Kitakasai, Edogawa-ku, Tokyo 134-8630, Japan

S. Miyakoshi: Present address: Gunma National College of Technology, 580, Toriba-machi, Maebashi, Gunma prefecture 371-8530, Japan

M. Inukai: Present address: Department of Pharmaceutical Sciences, International University of Health and Welfare, 2600-1, Kitakanemaru, Ohtawara, Tochigi prefecture 324-8501, Japan 


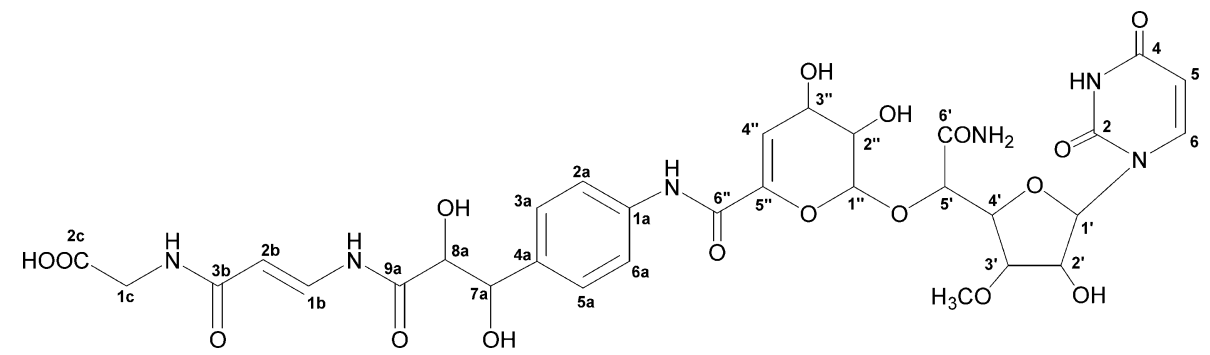

Fig. 1 Structure of A-102395.

Chemicals. Preparation methods for translocase I and a fluorescent substrate (UDP-MurNAc-L-Ala- $\gamma$-D-Glu- $m$ DAP-[ $N^{\varepsilon}$-dansyl]-D-Ala-D-Ala) were previously reported [10].

\section{Taxonomy of the Producing Organism}

The producing strain Amycolatopsis sp. SANK 60206 was isolated from a soil sample collected in Hokkaido, Japan. The methods and media described by the International Streptomyces Project (ISP) [19] and Waksman [20] were used to determine the morphological characterizations and the physiological properties of the producing organism. The cell walls and whole-cell hydrolysates were analyzed by the methods of Hasegawa et al. [21]. Lipid characterisitic of Nocardia spp., type A was analyzed by the method of Hecht [22]. The $16 \mathrm{~S}$ rDNA was amplified by the polymerase chain reaction using genomic DNA of the strain and sequenced. The most related sequences were searched using the BLAST algorithm in the National Center for Biotechnology Information (NCBI).

\section{Measurement of Translocase I Inhibitory Activity}

The measurement of translocase I inhibitory activity was carried out in 96-well microtitre polystyrene plate (Corning Coaster, \#3694) in $100 \mu \mathrm{l}$ containing $100 \mathrm{mM}$ Tris- $\mathrm{HCl}(\mathrm{pH} 7.5), 50 \mathrm{mM} \mathrm{KCl}, 25 \mathrm{mM} \mathrm{MgCl}_{2}, 0.8 \%$ Triton X-100, $166 \mu \mathrm{M}$ undecaprenyl phosphate and $70 \mu \mathrm{M}$ UDP-MurNAc-L-Ala- $\gamma$-D-Glu- $m$-DAP-[ $N^{\varepsilon}$-dansyl]-D-Ala$\mathrm{D}-\mathrm{Ala}$. The reaction was initiated by the addition of the enzyme $(0.625 \sim 2.5 \mu \mathrm{g}$ protein). The enzyme activity was monitored by measuring the increase in fluorescence at $538 \mathrm{~nm}$ (excitation at $355 \mathrm{~nm}$ ).

\section{Antimicrobial Activities}

MICs were determined by the agar dilution method using Mueller Hinton agar (Becton Dickinson and Company).

\section{General Experimental Procedures}

The various NMR spectra were obtained on a Bruker AVANCE 500 spectrometer. Methanol- $d_{4}$ and DMSO- $d_{6}$ were used as solvent and internal references. FAB-MS spectra were recorded on a JEOL JMS-700QQ mass spectrometer. Optical rotations were recorded on a JASCO DIP-370 spectropolarimeter. UV spectra were obtained on a Shimadzu UV-265FW spectrometer. Fluorescence was measured at room temperature on a fluorescence spectrophotometer, Fluoroskan Ascent (Labsystems).

\section{Results}

\section{Taxonomy}

The cell walls of the strain contained meso-diaminopimelic acid but not glycine. The whole cell sugars had arabinose and galactose in the major amount as the diagnostic component. No nocardomycolic acids were present in cells. The strain showed the highest level of 16S rRNA gene similarity with the type strain of Amycolatopsis rifamycinica (AY083603) (1340/1350, 99.3\%). Relatively high similarity values were shown with the type strains of Amycolatopsis lexingtonensis (AY183358) (1332/1345, 99.0\%), A. vancoresmycina (AJ508240) (1332/1345, $99.0 \%$ ). Based on the taxonomic properties, the strain was identified as Amycolatopsis sp. SANK 60206.

\section{Fermentation}

A loopful of a culture of strain SANK 60206 was inoculated into each of two 500-ml Erlenmeyer flasks containing $80 \mathrm{ml}$ of sterilized seed medium consisting of galactose $2.0 \%$, Bacto-Soytone (Difco) 1.0\%, glycerol $1.0 \%$, dextrin $2.0 \%$, corn steep liquor $0.5 \%$, sodium citrate $0.1 \%, \mathrm{Na}_{2} \mathrm{HPO}_{4} \cdot 12 \mathrm{H}_{2} \mathrm{O} 0.3 \%,\left(\mathrm{NH}_{4}\right)_{2} \mathrm{SO}_{4} 0.2 \%, \mathrm{CaCO}_{3}$ $0.2 \%$ and $\mathrm{CB}-442$ (NOF Co., Ltd.) $0.05 \%$. The inoculated flasks were incubated on a rotary shaker $(210 \mathrm{rpm})$ at $28^{\circ} \mathrm{C}$ for 3 days. The cultures were combined and then $2.0 \mathrm{ml}$ aliquots of the culture were transferred into each of sixtyfour 500-ml Erlenmeyer flasks containing $80 \mathrm{ml}$ of sterilized production medium consisting of the same seed medium. The inoculated flasks were incubated on a rotary shaker $(210 \mathrm{rpm})$ at $28^{\circ} \mathrm{C}$ for 6 days. 


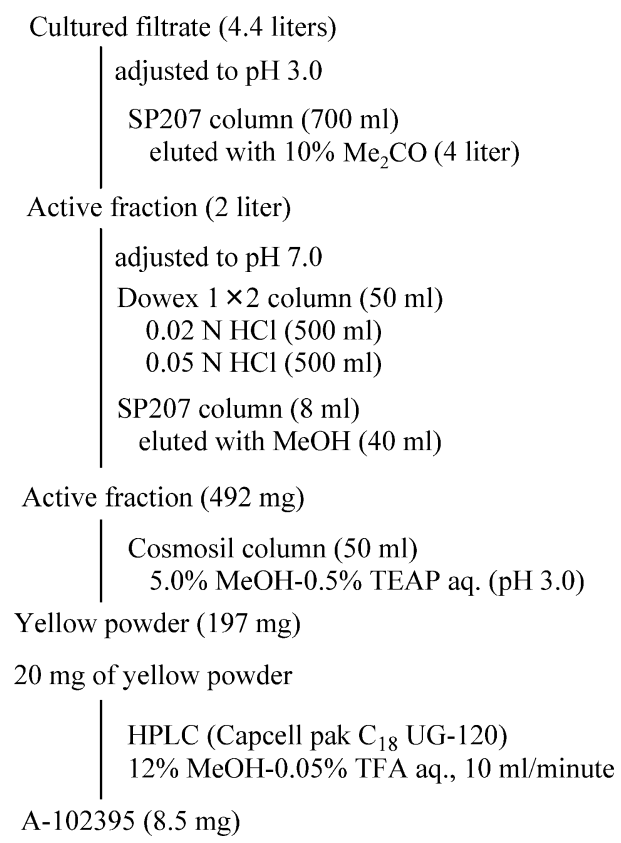

Fig. 2 Isolation procedures of A-102395.

\section{Isolation}

The isolation procedure of A-102395 is outlined in Fig. 2. First, 4.4 liters of the culture filtrate were adjusted to $\mathrm{pH}$ 3.0 with $1 \mathrm{M} \mathrm{HCl}$ and adsorbed onto a DIAION SP207 column $(700 \mathrm{ml})$. The column was washed with water and active substance was eluted with $10 \% \mathrm{Me}_{2} \mathrm{CO}$ (4 liters) fractionated into $20 \mathrm{ml}$ portions. The combined active fraction was concentrated in vacuo to remove $\mathrm{Me}_{2} \mathrm{CO}$ (2 liters) and adjusted to $\mathrm{pH} 7.0$ with $1 \mathrm{M} \mathrm{NaOH}$ and adsorbed onto a Dowex $1 \times 2$ column $(50 \mathrm{ml})$. The column was washed with water and the active substance was successively eluted with $0.02 \mathrm{M} \mathrm{HCl}(500 \mathrm{ml})$ and $0.05 \mathrm{M}$ $\mathrm{HCl}(500 \mathrm{ml})$ and fractionated in $20 \mathrm{ml}$ portions. Active fractions were collected, adjusted to $\mathrm{pH} 3.0$ with $1 \mathrm{M}$ $\mathrm{NaOH}$, subjected to SP207 column $(8 \mathrm{ml})$. After the column was washed with water, active substance was eluted with $\mathrm{MeOH}$ and concentrated in vacuo to give $492 \mathrm{mg}$ of brown powder. The powder was dissolved in $0.5 \%$ triethylamine phosphate (TEAP) aq. (pH 3.0, $2.5 \mathrm{ml}$ ) and applied onto a Cosmosil column $(50 \mathrm{ml})$. The column was washed with $0.5 \%$ TEAP aq. $(\mathrm{pH} 3.0,250 \mathrm{ml})$ and active substance was eluted with $5.0 \% \mathrm{MeOH}-0.5 \%$ TEAP aq. $(\mathrm{pH} 3.0,500 \mathrm{ml})$. The active fractions were collected, concentrated in vacuo to remove $\mathrm{MeOH}$ and subjected on SP207 column $(8 \mathrm{ml})$. After the column was washed with water, active substance was eluted with $\mathrm{MeOH}$ and concentrated in vacuo to give $197 \mathrm{mg}$ of yellow powder. Further, $20 \mathrm{mg}$ of this powder was dissolved into $2.0 \mathrm{ml}$ of $20 \% \mathrm{MeOH}$ aq. containing $0.05 \%$ TFA and each
Table 1 Physico-chemical properties of A-102395

\begin{tabular}{ll}
\hline Appearance & White powder \\
{$[\alpha]_{D}^{25}$} & $+70\left(c 0.8, \mathrm{H}_{2} \mathrm{O}\right)$ \\
UV $\lambda_{\max } \mathrm{nm}(\varepsilon)$ in $\mathrm{H}_{2} \mathrm{O}$ & $266(34,900)$ \\
Molecular formula & $\mathrm{C}_{31} \mathrm{H}_{36} \mathrm{~N}_{6} \mathrm{O}_{17}$ \\
FAB-MS $(m / z)$ & $765(\mathrm{M}+\mathrm{H})^{+}$ \\
HR-FAB-MS $(m / z)$ & \\
$\quad$ Found: & $787.2064(\mathrm{M}+\mathrm{Na})^{+}$ \\
$\quad$ Calcd.: & 787.2034 \\
IR $v_{\max }(\mathrm{KBr}) \mathrm{cm}^{-1}$ & $3336,3103,2934,1670,1528$, \\
& $1410,1251,1110,1058,978$ \\
\hline
\end{tabular}

$200 \mu$ portion of the solution was subjected to HPLC column (Capcell pak $\mathrm{C}_{18}$ UG-120, 20 i.d. $\times 250 \mathrm{~mm}$ ). The chromatography was performed 10 times with $12 \% \mathrm{MeOH}$ aq. containing $0.05 \%$ TFA at a flow rate of $10.0 \mathrm{ml} / \mathrm{minute}$, under the UV detection at $260 \mathrm{~nm}$. A-102395 was eluted at the retention time of 20.5 minutes. The HPLC fractions were concentrated and freeze-dried, to yield pure A-102395 as a white powder $(8.5 \mathrm{mg})$.

\section{Physico-chemical Properties}

Physico-chemical properties of A-102395 are summarized in Table 1. The molecular formula of A-102395 was determined by high resolution FAB-MS to be $\mathrm{C}_{31} \mathrm{H}_{36} \mathrm{~N}_{6} \mathrm{O}_{17}$. The UV spectrum of A-102395 in aqueous solution is characterized by a single maximum absorption at $266 \mathrm{~nm}(\varepsilon$ 34,900).

\section{Structure Elucidation}

The ${ }^{1} \mathrm{H}$ - and ${ }^{13} \mathrm{C}-\mathrm{NMR}$ assignments of A-102395 in methanol- $d_{4}$ are listed in Table 2 . In the ${ }^{13} \mathrm{C}$-NMR spectrum of A-102395, 29 carbon signals were observed. The multiplicity of carbon signals was determined by DEPT experiments. HSQC [23] experiment established all onebond ${ }^{1} \mathrm{H}-{ }^{13} \mathrm{C}$ connectivities. COSY [24] and HMBC [25] experiments clarified that the partial structure $\mathrm{A}$ of $\mathrm{A}$ 102395 (Fig. 3) was identical to that of capuramycin and A500359s [9]. Further analysis of the additional correlations of the signals revealed the partial structure $\mathrm{B}$ and $\mathrm{C}$ as follows. The ${ }^{1} \mathrm{H}_{-}{ }^{13} \mathrm{C}$ long range couplings of ${ }^{2} \mathrm{~J}$ and ${ }^{3} \mathrm{~J}$ observed in the $\mathrm{HMBC}$ experiment gave the following information. The cross peaks from $\mathrm{H}-2 \mathrm{a}$ and $\mathrm{H}-6 \mathrm{a}$ to $\mathrm{C}-1 \mathrm{a}$ and $\mathrm{C}-4 \mathrm{a}$, and from $\mathrm{H}-3 \mathrm{a}$ and $\mathrm{H}-5 \mathrm{a}$ to $\mathrm{C}-1 \mathrm{a}$ and $\mathrm{C}-4 \mathrm{a}$ as well as the coupling constant $(8.5 \mathrm{~Hz})$ obsearved between $\mathrm{H}-2 \mathrm{a} / \mathrm{H}-6 \mathrm{a}$ and $\mathrm{H}-3 \mathrm{a} / \mathrm{H}-5 \mathrm{a}$ suggested the presence of a 1,4disubstituted benzene. The cross peaks from H-8a to C-9a elucidated the structure from C-7a to C-9a. The cross peaks from $\mathrm{H}-7 \mathrm{a}$ to $\mathrm{C}-3 \mathrm{a}$ and $\mathrm{C}-5 \mathrm{a}$, and from $\mathrm{H}-8 \mathrm{a}$ to $\mathrm{C}-4 \mathrm{a}$ 
Table $2{ }^{13} \mathrm{C}$ - and ${ }^{1} \mathrm{H}-\mathrm{NMR}$ data for A-102395 in methanol$d_{4}$

\begin{tabular}{|c|c|c|}
\hline No. & $\delta_{\mathrm{C}}$ & $\delta_{\mathrm{H}}(\mathrm{J}=\mathrm{Hz})$ \\
\hline 2 & 152.3 & \\
\hline 4 & 166.3 & \\
\hline 5 & 102.8 & $5.73(1 \mathrm{H}, \mathrm{d}, 8.0)$ \\
\hline 6 & 142.0 & $7.85(1 \mathrm{H}, \mathrm{d}, 8.0)$ \\
\hline $1^{\prime}$ & 91.7 & $5.75(1 \mathrm{H}, \mathrm{d}, 3.0)$ \\
\hline $2^{\prime}$ & 74.1 & $4.25(1 \mathrm{H}, \mathrm{dd}, 3.0,5.0)$ \\
\hline $3^{\prime}$ & 80.1 & $3.73(1 \mathrm{H}, \mathrm{brt}, 5.0)$ \\
\hline $3^{\prime}-\mathrm{OCH}_{3}$ & 58.7 & $3.30(3 \mathrm{H}, \mathrm{s})$ \\
\hline $4^{\prime}$ & 81.3 & $4.50(1 \mathrm{H}, \mathrm{dd}, 2.0,5.0)$ \\
\hline $5^{\prime}$ & 77.4 & $4.83(1 \mathrm{H}, \mathrm{d}, 2.0)$ \\
\hline $6^{\prime}-\mathrm{CONH}_{2}$ & 174.0 & \\
\hline $1^{\prime \prime}$ & 101.1 & $5.28(1 \mathrm{H}, \mathrm{d}, 4.0)$ \\
\hline $2^{\prime \prime}$ & 67.5 & $4.09(1 \mathrm{H}, \mathrm{t}, 4.0)$ \\
\hline $3^{\prime \prime}$ & 63.7 & $4.44(1 \mathrm{H}, \mathrm{t}, 4.0)$ \\
\hline $4^{\prime \prime}$ & 110.7 & $6.07(1 \mathrm{H}, \mathrm{d}, 1.5)$ \\
\hline $5^{\prime \prime}$ & 144.2 & \\
\hline $6^{\prime \prime}$ & 161.7 & \\
\hline $1 \mathrm{a}$ & 138.2 & \\
\hline $2 a / 6 a$ & 122.1 & $7.62(2 \mathrm{H}, \mathrm{d}, 8.5)$ \\
\hline $3 a / 5 a$ & 128.3 & $7.41(2 \mathrm{H}, \mathrm{d}, 8.5)$ \\
\hline $4 a$ & 139.6 & \\
\hline $7 a$ & 75.4 & $5.03(1 \mathrm{H}, \mathrm{d}, 3.0)$ \\
\hline $8 a$ & 77.6 & $4.21(1 \mathrm{H}, \mathrm{d}, 3.0)$ \\
\hline $9 a$ & 174.1 & \\
\hline $1 b$ & 135.5 & $7.83(1 \mathrm{H}, \mathrm{d}, 14.0)$ \\
\hline $2 b$ & 106.3 & $5.93(1 \mathrm{H}, \mathrm{d}, 14.0)$ \\
\hline $3 b$ & 169.8 & \\
\hline $1 c$ & 42.2 & $3.96(2 \mathrm{H}, \mathrm{br} \mathrm{s})$ \\
\hline $2 c$ & 173.6 & \\
\hline
\end{tabular}

elucidated the connection between $\mathrm{C}-7 \mathrm{a}$ and benzene in the partial structure $\mathrm{B}$. The cross peaks from $\mathrm{H}-2 \mathrm{~b}$ to $\mathrm{C}-3 \mathrm{~b}$ and from $\mathrm{H}-1 \mathrm{c}$ to $\mathrm{C}-3 \mathrm{~b}$ and $\mathrm{C}-2 \mathrm{c}$ revealed the partial structure $\mathrm{C}$ from $\mathrm{C}-1 \mathrm{~b}$ to $\mathrm{C}-2 \mathrm{c}$. The geometrical configuration of the double bond at $\mathrm{C} 1 \mathrm{~b}-\mathrm{C} 2 \mathrm{~b}$ proved to be $E$ based on $J_{\mathrm{H} 1 \mathrm{~b}-\mathrm{H} 2 \mathrm{~b}}$ $(14.0 \mathrm{~Hz})$.

To determine the linkages between the three partial structures, a series of NMR experiments were performed again using DMSO- $d_{6}$ as a solvent. In the ${ }^{1} \mathrm{H}-\mathrm{NMR}$ using DMSO- $d_{6}$ as a solvent, additional three exchangeable proton signals, $\delta_{\mathrm{H}} 10.30, \delta_{\mathrm{H}} 9.80$ and $\delta_{\mathrm{H}} 8.20$ were observed. The connection between the partial structure A and B was established by the cross peaks from NH-6" $\left(\delta_{\mathrm{H}}\right.$ 9.80) to C-6", C-2a and C-6a. The connection between the partial structure $\mathrm{B}$ and $\mathrm{C}$ was determined by the cross peaks from $\mathrm{NH}-9 \mathrm{a}\left(\delta_{\mathrm{H}} 10.30\right)$ to $\mathrm{C}-9 \mathrm{a}$ as well as from $\mathrm{H}-8 \mathrm{a}$ and $\mathrm{H}-1 \mathrm{~b}$ to $\mathrm{C}-9 \mathrm{a}$ in $\mathrm{HMBC}$ spectrum. The last exchangeable proton $\left(\delta_{\mathrm{H}} 8.20\right)$ was assigned to NH-3b by HMBC cross peaks from $\delta_{\mathrm{H}} 8.20$ to C-3b.

From its molecular formula, two carbonyl residues, C- $6^{\prime}$ and $\mathrm{C}-2 \mathrm{c}$, were expected to form amide or carboxylate group. To determine which carbon formed carboxylate group, A-102395 was converted to the methyl ester derivative by TMS-diazomethane. In HMBC experiment of this derivative (using methanol- $d_{4}$ as solvent), the long range coupling from $\delta_{\mathrm{H}} 3.72$ of methoxy proton to C-2c was observed. It was proved that $\mathrm{C}-2 \mathrm{c}$ formed carboxylate group and C-6' formed amide group. The planer structure of A-102395 was concluded to be as shown in Fig. 1.

\section{Biological Activities of A-102395}

A-102395 inhibited translocase I with $\mathrm{IC}_{50}$ value of $11 \mathrm{nM}$, but did not show any antimicrobial activity against Grampositive and -negative bacteria tested.

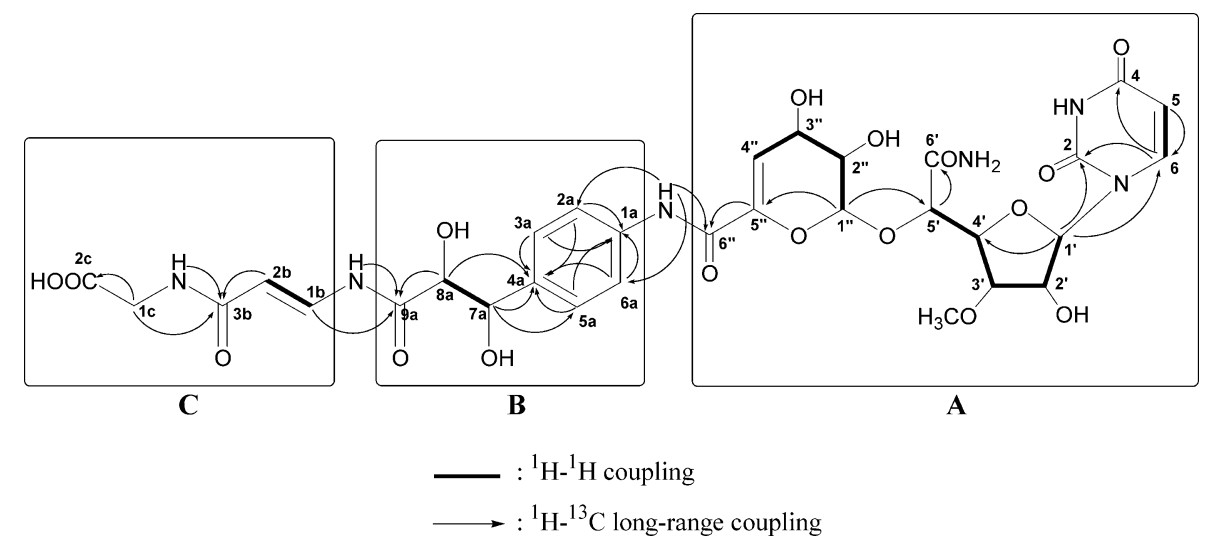

Fig. $3{ }^{1} \mathrm{H}-{ }^{-1} \mathrm{H}$ and ${ }^{1} \mathrm{H}^{13}{ }^{13} \mathrm{C}$ long-range correlations of $\mathrm{A}-102395$. 


\section{Discussion}

A new capuramycin derivative, A-102395, was isolated from the fermentation broth of the strain identified as Amycolatopsis sp. SANK 60206. A-102395 showed the potent inhibitory activity for bacterial translocase I with $\mathrm{IC}_{50}$ values of $11 \mathrm{nM}$. The inhibitory activity of A-102395 is as potent as that of capuramycin $\left(\mathrm{IC}_{50}: 18 \mathrm{nM}\right)$ [10]. In the previous studies of capuramycin and A-500359s [10, $11]$, we revealed the core skeleton (2'-methoxyuridine attached an unsaturated uronic acid moiety) was necessary for the inhibition of translocase I. Compared with the structure of A-102395, the core skeleton (partial structure A) is the same as of capuramycin, but A-102395 has the benzene with a uniquely substituted chain instead of an aminocaprolactam. So, it is considered that the potency of the inhibition of translocase I by A-102395 basically comes from the core skeleton, and the other structural features may influence the activity.

A-102395 had potent inhibitory activity for bacterial translocase I, but lacked antimicrobial activity against various strains tested. In the previous studies, it revealed capuramycin and A-500359s showed antimicrobial activities against S. pneumoniae and Mycobacterium. We think A102395 has the potency for antimicrobial activity, but the poor permeability of the bacterial membrane may cause the lack of the antimicrobial activity. There are some compounds reported as translocase I inhibitors. Most of them are also natural products containing a nucleoside moiety and have unique spectra of antimicrobial activity. Mureidomycins, pacidamycins and napsamycins are closely related compounds containing a 3 '-deoxyuridine attached a peptide chain, and active against Pseudomonas strains. Liposidomycins and caprazamycins are uridine compounds containing a diazepine, and an acyl moiety. They have potent antimicrobial activity against Mycobacterium. These limited spectra of antimicrobial activity also may be due to a permeability of the bacterial membrane. In the recent reports, some of synthesized analogues of pacidamycins [26], liposidomycins [27], capuramycin [28, 29] and caprazamycins $[30,31]$ showed broader spectrum and more potent antimicrobial activity. So, there is possibility that some chemical modification of A-102395 at the C-2c or the chain attached to benzene may improve the antimicrobial activity.

Previously, we discovered capuramycin related compounds, A-500359s and A-503083 [32]. Though these producing strains were classified into Streptomyces sp., the producing strain of A-102395 is distinct from them taxonomically. It is interesting to note that strains belong to different families of actinomycetes produce similar compounds. It is possible that both of producing organisms share common biosynthetic genes and synthesize the core skeleton of capuramycin via the identical biosynthetic pathway. Therefore, these producing organisms may be useful to study for biosynthesis of capuamycin.

\section{References}

1. Brandish PE, Kimura K, Inukai M, Southgate R, Lonsdale JT, Bugg TD. Modes of action of tunicamycin, liposidomycin B and mureidomycin A: Inhibition of phospho- $N$-acetylmuramyl-pentapeptide translocase from Escherichia coli. Antimicrob Agents Chemother 40: 1640-1644 (1996)

2. Inukai M, Isono F, Takahashi S, Enokita R, Sakaida Y, Haneishi T. Mureidomycin A D , novel peptidylnucleoside antibiotics with spheroplast forming activity. I. Taxonomy, fermentation, isolation and physico-chemical properties. J Antibiot 42: 662-666 (1989)

3. Karwowski JP, Jackson M, Theriault RJ, Chen RH, Barlow GJ, Maus ML. Pacidamycins, a novel series of antibiotics with anti-Pseudomonas aeruginosa activity. I. Taxonomy of the producing organism and fermentation. J Antibiot 42: 506-511 (1989)

4. Chatterjee S, Nadkarni SR, Vijayakumar EK, Patel MV, Ganguli BN, Fehlhaber HW, Vertesy L. Napsamycins, new Pseudomonas activity antibiotics of mureidomycin family from Streptomyces sp. HIL Y-82, 11372. J Antibiot 47: 595-598 (1994)

5. Ubukata $\mathrm{M}$, Isono $\mathrm{K}$. The structure of liposidomycin $\mathrm{B}$, an inhibitor of bacterial peptidoglycan synthesis. J Am Chem Soc 110: 4416-4417 (1988)

6. Takatsuki A, Arima K, Tamura G. Tunicamycin, a new antibiotic. I. Isolation and characterization of tunicamycin. J Antibiot 24: 215-223 (1971)

7. Yamaguchi H, Sato S, Yoshida S, Takada K, Itou M, Seto H, Otake N. Capuramycin, a new nucleoside antibiotic. Taxonomy, fermentation, isolation and characterization. J Antibiot 39: 1047-1053 (1986)

8. Seto H, Otake N. The structure of a new nucleoside antibiotic, capuramycin. Tetrahedron Lett 29: 2343-2346 (1988)

9. Muramatsu Y, Muramatsu A, Ohnuki T, Ishi MM, Kizuka M, Enokita R, Tsutsumi S, Arai M, Ogawa Y, Suzuki T, Takatsu T, Inukai M. Studies on novel bacterial translocase I inhibitors. I. Taxonomy, fermentation, isolation, physicochemical properties and structure elucidation of A500359A, C, D and G. J Antibiot 56: 243-252 (2003)

10. Muramatsu Y, Ishii MM, Inukai M. Studies on novel bacterial translocase I inhibitors, A-500359s. II. Biological activities of A-500359 A, C, D and G. J Antibiot 56: 253-258 (2003) 
11. Muramatsu Y, Miyakoshi S, Ogawa Y, Ohnuki T, Ishii MM, Arai M, Inukai M. Studies on novel bacterial translocase I inhibitors, A-500359s. III. Deaminocaprolactam derivaties of capuramycin: A-500359 E, F, H, M-1 and M-2. J Antibiot 56: 259-267 (2003)

12. Ohnuki T, Muramatsu Y, Miyakoshi S, Takatsu T, Inukai M. Studies on novel bacterial translocase I inhibitors, A500359s. IV. Biosynthesis of A-500359s. J Antibiot 56: 268-279 (2003)

13. Muramatsu Y, Arai M, Sakaida Y, Takamatsu Y, Miyakoshi $\mathrm{S}$, Inukai M. Studies on novel bacterial translocase I inhibitors, A-500359s. V. Enhanced production of capuramycin and A-500359A in Streptomyces griseus SANK 60196. J Antibiot 59: 601-606 (2006)

14. Mcdonald LA, Barbieri LR, Carter GT, Lenoy E, Lotvin J, Petersen PJ, Singh G, Williamson RT. Structures of the muraymycins, novel peptidoglycan biosynthesis inhibitors. J Am Chem Soc 124: 10260-10261 (2002)

15. Igarashi M, Nakagawa N, Doi N, Hattori S, Naganawa H, Hamada M. Caprazamycin B, a novel anti-tuberculosis antibiotic, from Streptomyces sp. J Antibiot 56: 580-583 (2003)

16. Igarashi M, Takahashi Y, Shibata T, Nakamura H, Naganawa H, Miyake T, Akamatsu Y. Caprazamycins, novel liponucleoside antibiotics, from Streptomyces sp. II. Structure elucidation of caprazamycins. J Antibiot 58: 327-337 (2005)

17. Fernandes PB, Swanson RN, Hardy DJ, Hanson CW, Coen L, Rasmussen RR, Chen RH. Pacidamycins, a novel series of antibiotics with anti-Pseudomonas aeruginosa activity. III. Microbiologic profile. J Antibiot 42: 521-526 (1989)

18. Isono F, Kodama K, Inukai M. Susceptibility of Pseudomonas species to the novel antibiotics mureidomycins. Antimicrob Agents Chemother 36: 1024-1027 (1992)

19. Shirling EB, Gottlieb D. Methods for characterization of Streptomyces species. Int J Syst Bacteriol 16: 313-340 (1966)

20. Waksman SA. Classification, identification and description of genera and species. The Actinomycetes. Vol. II: pp. 328-334, Williams \& Wilkins (1961)

21. Hasegawa T, Takizawa M, Tanida S. A rapid analysis for chemical grouping of aerobic actinomycetes. J Gen Appl Microbiol 29: 319-322 (1983)

22. Hecht ST, Causey WA. Rapid method for the detection and identification of mycolic acids in aerobic actinomycetes and related bacteria. J Clin Microbiol 4: 284-287 (1976)

23. Kay LE, Keifer P, Saarinen T. Pure absorption gradient enhanced heteronuclear single quantum correlation spectroscopy with improved sensitivity. J Am Chem Soc 114: 10663-10665 (1992)

24. Davis AL, Laue ED, Keeler J, Moskau D, Lohman J.
Absorption-mode two-dimensional NMR spectra recorded using pulsed field gradients. J Magn Reson 94: 637-644 (1991)

25. Willker W, Leibfritz D, Kerssebaum R, Bermel W. Gradient selection in inverse heteronuclear correlation spectroscopy. Magn Reson Chem 31: 287-292 (1993)

26. Constantine GB, Remy CL, Johanne B, Nicole GV, Karin AS, Angela M, Suzanne C, Scott JH, Ving JL. Synthetic dihydropacidamycin antibiotics: A modified spectrum of activity for the pacidamycin class. Bioorg Med Chem Lett 13: 3305-3309 (2003)

27. Dini C, Didier-Laurent S, Drochon N, Feteanu S, Guillot JC, Monti F, Uridat E, Zhang J, Aszodi J. Synthesis of submicromolar inhibitors of MraY by exploring the region originally occupied by the diazepanone ring in the liposidomycin structure. Bioorg Med Chem Lett 12: 1209-1213 (2002)

28. Hotoda H, Furukawa M, Daigo M, Murayama K, Kaneko M, Muramatsu Y, Ishi MM, Miyakoshi S, Takatsu T, Inukai M, Kakuta M, Abe T, Harasaki T, Fukuoka T, Utsui Y, Ohya S. Synthesis and antimycobacterial activity of capuramycin analogues. Part 1: Substitution of the azepan-2-one moiety of capuramycin. Bioorg Med Chem Lett 13: 2829-2832 (2003)

29. Hotoda H, Daigo M, Furukawa M, Murayama K, Hasegawa AC, Kaneko M, Muramatsu Y, Ishi MM, Miyakoshi S, Takatsu T, Inukai M, Kakuta M, Abe T, Fukuoka T, Utsui Y, Ohya S. Synthesis and antimycobacterial activity of capuramycin analogues. Part 2: Acylated derivatives of capuramycin-related compounds. Bioorg Med Chem Lett 13: 2833-2836 (2003)

30. Miyake T, Takahashi Y, Igarashi M, Doi N, Shitara T, Sohtome H, Iijima K, Masuda T, Hattori S, Nakagawa N, Akamatsu Y. Novel semisynthetic antibiotics from caprazamycins (Part1): Caprazene derivatives and their antiMycobacterium tuberculosis activity. 43rd Interscience Conference on Antimicrobial Agents and Chemotherapy (ICAAC), Abstracts F-2140 (2003)

31. Miyake T, Shitara T, Igarashi M, Doi N, Takahashi Y, Sohtome H, Iijima K, Masuda T, Hattori S, Nakagawa N, Akamatsu Y. Novel semisynthetic antibiotics from caprazamycins (Part 2): Caprazol derivatives and their antiMycobacterium tuberculosis activity. 43rd Interscience Conference on Antimicrobial Agents and Chemotherapy (ICAAC), Abstracts F-2141 (2003)

32. Muramatsu Y, Ohnuki T, Ishi MM, Kizuka M, Enokita R, Miyakoshi S, Takatsu T, Inukai M. A-503083 A, B, E and F, Novel inhibitors of bacterial translocase I, produced by Streptomyces sp. SANK 62799. J Antibiot 57: 639-646 (2004) 